\title{
ЯЗЫКОЗНАНИЕ
}

\author{
UDC 811.113.4
}

Elena Krasnova

St. Petersburg State University

\section{TYPES OF NOVEL COMPOUNDS IN DANISH*}

For citation: Krasnova E. Types of novel compounds in Danish. Scandinavian Philology, 2019, vol. 17, issue 2, pp. 207-216.

https://doi.org/10.21638/11701/spbu21.2019.201

Compounding as the most productive way of word formation in Danish, where an unlimited number of compounds can be formed, presupposes a continuous word formation process meaning creation of both potential and novel compounds, and a native speaker is often unaware that a word they create is beyond the scope of dictionaries. Novel compounds is a term to characterize words formed "occasionally", within a particular context of speech communication and, as a rule, inconsistent with the language norm, i. e. not in line with conventional ways of word formation in this language. However, this definition can hardly be applied to most novel compounds in Scandinavian languages, in Danish in particular. True, interesting compounds are being created daily in the course of speech communication; many of them to a greater or lesser extent demonstrate deviation from customary rules, but the question is whether they actually contradict the language norm or the effect of novelty arises by some other means and not as the result of the language norm violation. In modern linguistics, the term "novel compound" certainly needs a closer definition not only within a dichotomy "potential compound - novel compound". Novel compounds are most various as regards structure and formation semantics. That is why it is of prime importance to develop a typology of compounds created with a deviation from conventional word-forming patterns. This article attempts to present most common types of novel compounds. The study material includes publications in Danish mass media and the Danish Corpus. The study of major types of novel compounds in modern Danish suggests that almost all these units

\footnotetext{
${ }^{*}$ Supported by the RFFI Grant 19-012-00146.
} 
have a systemic character while deviation from compounding laws often turns out to be "legitimate" and can be traced to models already existing in the language.

Keywords: Danish language, word formation, compounding, potential compound words, novel compounds.

Novel compounds is a term to characterize words formed "occasionally", within a particular context of speech communication and, as a rule, inconsistent with the language norm, i. e. not in line with conventional ways of word formation in this language.

However, this definition can hardly be applied to most novel compounds in Scandinavian languages, in Danish in particular. True, interesting compounds are being created daily in the course of speech communication; many of them to a greater or lesser extent demonstrate deviation from customary rules, but the question is whether they actually contradict the language norm or the effect of novelty arises by some other means and not as the result of the language norm violation.

Compounding as the most productive way of word formation in Danish, where an unlimited number of compounds can be formed, presupposes a continuous word formation process meaning creation of both potential and novel compounds, and a native speaker is often unaware that a word they create is beyond the scope of dictionaries.

A "novel compound" is an element of a trine which also includes a "potential compound" and an "existing compound" ("lexicalized compound"). It is not always possible in the modern Danish to draw a clear line between potential and novel compounds because in some cases the line is blurred [Krasnova, 2017]. At the same time, lexicography needs criteria to differentiate between occasional words and new words of the standard language. The problem is particularly topical today when we constantly meet new words and expressions in mass media.

In modern linguistics, the term "novel compound" certainly needs a closer definition not only within a dichotomy "potential compound novel compound". Novel compounds are most various as regards structure and formation semantics. That is why it is of prime importance to develop a typology of compounds created with a deviation from conventional word-forming patterns. This article attempts to present most common types of novel compounds. The study material includes publications in Danish mass media and the Danish Corpus [https://ordnet. $\mathrm{dk} /$ korpusdk]. 
Whereas the study focuses on the typology of novel compounds, it is necessary to briefly define principles of selection of the study material, in particular, which units, not registered in dictionaries, remained beyond the framework of this study. The material does not include so-called potential words, not registered in dictionaries, but created according to established word-forming patterns and easily interpreted by native speakers. For Scandinavian languages, we cannot doubt the existence of potential compounds, which "possibly exist" and which should not be joined with novel compounds. Such potential compounds involve lexical differentiation, they lack expressiveness, and, as a rule, they can be easily interpreted. In the table below, of compounds with the second component 'telt' ('tent'), words in the right column (not registered in dictionaries) are roughly the same as words in the left column. They are created according to established word-forming patterns, their components have similar semantic relations, and they cannot be misinterpreted. In the Danish language, absence in dictionaries cannot be a criterion of a novel compound, that is why such units (similar to examples in the right column) were not included in the study material.

\begin{tabular}{|l|l|}
\hline \multicolumn{1}{|c|}{$\begin{array}{c}\text { Registered in Den danske ordbog } \\
\text { (https://ordnet.dk/ddo) }\end{array}$} & \multicolumn{1}{c|}{ Not registered in dictionaries } \\
\hline skydetelt 'shoot + tent' & $\begin{array}{l}\text { dansetelt 'dance + tent', spisetelt } \\
\text { 'eat + tent' }\end{array}$ \\
\hline cirkustelt 'cirkus + tent' & $\begin{array}{l}\text { festtelt 'festive occasion + tent', messetelt } \\
\text { 'trade fair + tent' }\end{array}$ \\
\hline $\begin{array}{l}\text { beduintelt 'Bedouin + tent', indianertelt } \\
\text { 'Indian + tent' }\end{array}$ & pressetelt 'press + tent' \\
\hline øltelt 'ale + tent' & madtelt 'food + tent' \\
\hline
\end{tabular}

In contrast to the compounds in the table above the occasional (or novel) compound asyltelt 'asylum + tent' demonstrates lack of connection between the first and the second components (the tent here is not a tent where you can get asylum, but a place where those who seek asylum live on a temporary basis).

Lack of a direct connection between the first and the second components (ellipsis or omission of some elements), dependence on the con- 
text, and novelty effect are usually considered principal features of a novel compound [Vashunin, 1983]. At the same time, in Danish we observe a rich variety both of nominative $\mathrm{N}+\mathrm{N}$ compounds that are traditionally described in the majority of works about word-formation in German philology, and of other structural types [Adams, 2001; Bauer, 1983; Booij, 2005; Downing, 1977; Marchand, 1969]. Those nominative novel units are most frequent and can be subdivided into several sub-types.

\section{1. $\mathrm{N}+\mathrm{N}$ compounds}

\section{1a. $\mathrm{N}+\mathrm{N}$ compounds that require a broader context, know- ledge about a topical event, or a specific discussion}

For example, smykkelov (verbatim jewel + law) "a law under which refugees from Syria must turn in valuable jewelry", tobaksenke (verbatim tobacco + widow) "a widow of the owner of a big tobacco factory".

When such novel compounds are being created in the course of speech communication, intermediate structural elements (specified by the context) are often omitted leaving the essence to mark the situation - and finally we get a contracted statement, a one-time unit existing only within the context. Obviously, such "contraction" of a long syntactic construction into a compact two-component word is made according to the speaker's preferences and attitude.

At the same time, in spite of non-transparency of such units for a recipient who is not familiar with a particular situation or discussion, they all are formed following a conventional pattern, with the first element determinative to a varying degree. As regards their structure, they do not deviate from the language norm and follow habitual ways of word formation in the language. Besides, it is not necessary that such units are used exclusively in a particular context. They can be repeated and reproduced.

\section{1b. $N+N$ compounds that do not need a broader context, knowledge about a topical event, or a specific discussion}

This group compounds do not refer to a particular situation, event, or discussion. Interpretation of such compounds is easier partly because it is easy to re-establish connections between the components, partly because there exist similar models, and partly because they are based on logical associations clear to native speakers. A compound sommerben (summer + legs) 'sun-tanned legs' does not require additional knowledge because summer is associated with suntan; the meaning of 
skraldesø (waste + lake) 'polluted lake with a lot of waste floating at the shores' is also easily understood without a direct connection between the components.

In some cases, it is useful to study such compounds in the context of metonymic transfer. For example, nouns that are metonymic names of a group of people or an organization are freely used as the first component in many compounds with 'konflikt' (in the sense of "conflict between employees and employers over compensation and work conditions") as the second component: buskonflikt (bus 'bus' to name bus drivers), havnekonflikt (havn 'port' to name dock workers), lægekonflikt (læge 'doctor' to name medical personnel of a hospital), skolekonflikt (skole 'school' to name school teachers), skraldekonflikt (skrald 'garbage' to name trash pickup companies). Analogy effect should also be considered since the second component is used in frequently occurring compounds like arbejdskonflikt (work+ conflict), storkonflikt (big + conflict). This model can serve as a base for future formations as well.

Such structurally occasional formations evidently have some limitations, i. e. there are some "allowable" or most frequent types of metonymic transfers. Most widely met are compounds in which complete identification of a certain situation comes down to an object component - when an object involved in an event or action is used instead of naming this event or action: asbestskandale (verbatim 'asbestos scandal' - about a scandal that occurred after information had been published that Danish railroads use prohibited asbestos).

We can hardly agree with some authors who name such words "structurally unmotivated" and argue that the lack of structural motivation is a result of an absence of direct semantic connections between the compound components which reflects the absence of such connections between real objects denoted by the compound components [Meshkov, 1986, p. 104]. Unless such connections existed, the formation of compounds would hardly be possible at all.

A compositional analysis shows that compounds of both above-mentioned types can contain an abbreviation as the first component. Such units only formally belong to novel compounds. In fact, they are systemic formations where the first component denoting an organization or a company is determinative (B\&O-direktør 'Bang \& Olufsen + director', i. e. CEO of Bang \& Olufsen; WTO-vilkår 'WTO + conditions', i. e. conditions imposed by WTO). 
One of the subtypes of novel compounds is a group of compounds with a proper name as the first component (Syrien-retræte 'Syria + retreat', Trump-anklager 'Trump + accusations'). Recently the group has been joined by novel compounds with names of TV programmes, shows or films as the first component, which may also be in English (De unge mødre-seerne " "Young Mothers" + spectators', Gift ved første blik-par " "Let's Get Married" + pair, "Game of thrones-stjerne" ' "Game of Thrones" + star').

Since compounding is often used to identify a new object, phenomenon, or process by its individual, concretizing feature, this concretization may as well use metaphors. While studying the metaphor in compounds, of prime interest are culturally-specific metaphoric compounds reflecting actual events and the unique perception of the text's author of objects, phenomena, and their relationship.

We can observe metaphorization in the first (burkabil 'burka + car') or the second component of a compound (baby-hær 'baby+army') as well as in a compound as a whole (kommandobro 'command + bridge' (captain's bridge)).

\section{Verbal compounds}

2a. One of frequently met models is back formation from a compound with a verbal noun as the second component denoting action noun (nomina actionis): landing'

nødlandning 'emergency landing' > nødlande 'make an emergency

politianmeldelse 'police report' > politianmelde 'file a police report' snerydning 'snow removal' > snerydde 'remove snow'.

Lately we have observed an increasing number of such compounds in mass media. On the one hand, they produce novelty effect and attract attention, on the other hand, they are not perceived as deviation from the language norm.

2b. Some verbal compounds originated from agent nouns (nomina agentis): fredsmægler 'peacemaker' > fredsmægle 'make peace', knivstikker 'a person who stabs with a knife' > knivstikke 'stab with a knife', seriemorder 'serial killer' > seriemyrde 'to kill in series', skattesvindler 'tax fraudster' > skattesvindle 'fraud with tax'.

2c. Some verbal compounds with the second verbal component originated from compounds with a participle as the second component: 
landsdækkende 'nationwide' > landsdække 'cover the whole land' solbeskyttende 'sun protecting' > solbeskytte 'protect against sun' strejkeramt 'affected by the strike' > strejkeramme 'affect by the strike' terrormistænkt 'terror suspected'> terrormistænke 'suspect of terror'

\section{Coordinating (copulative) compounds.}

Components of a copulative compound can have antonymous, or opposite, conflicting relations (nemsvær 'easy+difficult', dum-klog 'stupid+intelligent', horisontal-vertikal 'horizontal+vertical', lys/ skygge-virkninger 'light + shade + effects'); in rare cases - synonymous relations when two components are if not synonyms, still very close in meaning (tegne-male 'draw + paint').

However, most frequent are compounds whose components are different, but not opposite in meaning (lærer-forsker 'scientist + researcher', forfatter-onkel 'writer + uncle').

The analysis of coordinating compounds in the Danish Corpus and mass media reveals a tendency to use copulative compounds not isolated, but as the first component of a determinative compound, suggesting that they "tend" towards the most common in Danish attributive type (saltpeber-sæt 'salt + pepper + set', olie-eddike-dressing 'oil + vinegar + sauce').

Widely spread are abstract nouns from the fields of psychology, pedagogics, business and advertising that become "fashionable": mor-datterforhold 'mother + daughter + interaction', mor-datter-relationer 'mother + daughter + relations', mor-datter-ferie 'mother + daughter + vacation', mor-datter-dag 'mother + daughter + day', mor-datter-konflikt 'mother + daughter + conflict', lærer-elev-relationer 'teacher + student + relations', lærer-elev-forhold 'teacher + student + interaction', lærer-elev-konflikt 'teacher + student + conflict', lærer-elev fodboldkamp 'teacher + student + football game'. As a result, various series are created in a similar way, with some of these models loaned from English and further developed using Danish material.

A group of coordinating verbs is not numerous and most of them denote two actions (as a rule, expressed by infinitives) or an impulse to act (expressed by verbs in the imperative). In a coordinating compound, such verbs become determinative for the second component a noun: loese- stave troning 'read + write + training', tale-loese poedagog 'write + read + teacher', grave-loesse-maskine 'dig + load + vehicle', vis/ skjul funktion 'show + hide + function'. 
Copulative compounds which become the first component of a three-component unit can also be represented by prepositions (før/ efter-billede 'before and after + photo').

Isolated copulative compounds are a relatively small group in the Danish language. However, their ability to be used within three-component formations significantly changes their status. Most part of coordinating compounds in modern Danish is used as the first component of a determinative composite, i. e. they are modelled after actual words, which confirms their systemic character. The structure of a three-component compound with a coordinating compound as the first part is more complicated than that of a common determinative word with three components, it is no longer a binary structure: on the one hand, a coordinating compound becomes determinative for the third component, on the other hand, separate relations are formed in parallel between each of the two components of a coordinating compound and the third component. The structure of the mentioned above compound før/efter-billede 'before and after + photo can thus be illustrated by two patterns:

$$
\begin{array}{ll}
\text { før/efter }- \text { billede } & \text { før }<\text { billede } \\
\text { efter }<\text { billede }
\end{array}
$$

The study of major types of novel compounds in modern Danish suggests that almost all these units have a systemic character while deviation from compounding laws often turns out to be "legitimate" and can be traced to models already existing in the language. They are modelled after actual words and have a determinative character with the first component concretizing the second one. Some similarly "non-transparent" at first sight compounds also demonstrate a linguistically systemic character because the first component is somehow connected through a metonymic transfer with the initial situation, phenomenon, or object.

Evidently, only some individual novel compounds that appeared as a result of deviation from the "language word-formative standard" ("a language game") can be considered as non-systemic formations.

\section{REFERENCES}

Adams V. Complex Words in English. Harlow: Pearson Education Limited, 2001. $173 \mathrm{p}$.

Bauer L. English Word-Formation. Cambridge: Cambridge University Press, 1983. $311 \mathrm{p}$. 
Booij G. The Grammar of Words. Oxford: Oxford University Press, 2005. 308 p. Downing P. On the creation and use of English compound nouns. Language. 1977. No. 53. P. 810-842.

KorpusDK. Availabke at: https://ordnet.dk/korpusdk (accessed: 22.10.2019).

Krasnova E. On the differentiation of potential and occasional compounds in Danish. Romano-germanistika. St. Petersburg, 2017. P. 33-37. (In Russian)

Meshkov O. Semantic aspects of English compounding. Moscow: Nauka Publ., 1986. 208 p. (In Russian)

Marchand H. The Categories and Types of present-day English Word Formation. Second Edition. Wiesbaden: Otto Harrassowitz, 1969. 379 p.

Vashunin V. Occasional compounds in German from the a communicative-pragmatic point of view. Tekst. Vyskazyvanie. Slovo. Moscow, 1983. P. 164-175. (In Russian)

\section{Елена Краснова \\ Санкт-Петербургский государственный университет}

\section{ТИПОЛОГИЯ ОККАЗИОНАЛЬНЫХ СЛОЖНЫХ СЛОВ В ДАТСКОМ ЯЗЫКЕ*}

Для цитирования: Krasnova E. Types of novel compounds in Danish // Скандинавская филология. 2019. Т. 17. Вып. 2. С. 207-216. https://doi.org/10.21638/11701/spbu21.2019.201

Статус словосложения как наиболее продуктивного способа словообразования в датском языке, где возможно образование безграничного количества сложных слов, предполагает непрерывный словообразовательный процесс, а значит и создание как потенциальных, так и окказиональных сложных слов, и носитель языка зачастую не отдает себе отчет в том, что созданное им слово находится за пределами словарей. Окказионализмами обычно называют слова, образуемые «по случаю» в конкретных условиях речевой коммуникации и, как правило, противоречащие языковой норме, то есть не соответствующие привычным способам образования слов в данном языке. Однако для большинства окказиональных сложных слов в скандинавских языках и, в частности, в датском, это определение вряд ли может быть использовано. Действительно, в процессе речевой коммуникации ежедневно создаются композиты, привлекающие внимание, многие из них в большей или меньшей степени демонстрируют нарушение привычных правил, но возникает вопрос: противоречат ли они в действительности языковой норме или же эффект новизны возникает без нарушения языковой нормы - за счет каких-то других механизмов? Первостепенной задачей является создание типологии композитов, созданных с нарушением общепринятых словообразовательных моделей. В данной статье делается попытка представить наиболее распространенные типы окказиональных сложных слов в датском языке. Материалом исследования стали публикации датских СМИ, а также Корпус датского языка. В статье рассматриваются различные типы окка-

\footnotetext{
* При поддержке гранта РФФИ 19-012-00146.
} 
зиональных номинативных образований, окказиональные глагольные композиты, а также сочинительные образования разного типа. Рассмотрение основных типов окказиональных сложных слов в современном датском языке свидетельствует о том, что практически все единицы имеют системный характер, а нарушение законов словосложения нередко оказывается «легитимным» и может быть возведено к существующим в языке моделям. Они создаются по образцу узуальных слов и имеют детерминативный характер - первый компонент конкретизирует второй. Отдельные, на первый взгляд, «непрозрачные» композиты также демонстрируют лингвистически системный характер, потому что первый компонент так или иначе связан по смежности с исходной ситуацией, явлением или предметом.

Ключевые слова: датский язык, словообразование, словосложение, потенциальные сложные слова, окказиональные сложные слова.

\section{Elena Krasnova}

Associate professor,

St. Petersburg State University,

7-9, Universitetskaya nab., St. Petersburg, 199034, Russia

E-mail: e.krasnova@spbu.ru

\section{Краснова Елена Всеволодовна}

доцент, кандидат филологических наук,

Санкт-Петербургский государственный университет,

Россия, 199034, Санкт-Петербург, Университетская наб., 7-9

E-mail: e.krasnova@spbu.ru

Received: September 03, 2019

Accepted: October 16, 2019 